\title{
Neurogenic tumours with an intrathoracic localization
}

\author{
W. M. OOSTER W I JK AND J. SWIERENGA \\ From the Departments of Lung Diseases and Surgery of the St. Antonius Hospital, Utrecht, \\ The Netherlands
}

This paper is a clinicopathological review of patients suffering from intrathoracic neurogenic tumours.

Neurogenic tumours form one of the most frequent anomalies of the mediastinum. In the material of our department this diagnosis was made in $15 \%$ of the patients who had an affection of the mediastinum. Only intrathoracic and retrosternal struma occurred with a slightly higher frequency than neurogenic tumours.

The literature contains numerous papers on intrathoracically localized neurogenic tumours (Kent, Blades, Valle, and Graham, 1944 ; Blades, 1946 ; Ackerman and Taylor, 1951 ; Ringertz and Lidholm, 1956 ; Schweisguth, Mathey, Renault, and Binet, 1959 ; Oberman and Abell, 1960 ; Carey, Ellis, Good, and Woolner, 1960 ; Pachter, 1963 ; Diané, 1965 ; Razemon and Ribet, 1965 ; Dor, Houel, Reboud, Longefait, and Malméjac, 1965 ; Jaubert de Beaujeu and Maret, 1965 ; Meyer and Ochsner, 1966). Most of these papers concern limited aspects of such lesions. It therefore seemed useful to study these tumours in a large series of cases.

The material of St. Antonius Hospital comprised the records of 53 patients who had an intrathoracic neurogenic tumour; with the addition of material from a few other Dutch hospitals data were collected forming a total of 111 cases.

\section{EMBRYOLOGY}

The nomenclature of neurogenic tumours is confusing. To understand the various classifications used for these tumours requires a knowledge of certain aspects of development, because many neurogenic tumours contain cells derived from various developmental stages of the nervous system. The so-called neural crest is important in the origin of the peripheral nervous system. This region of the ectoderm situated at the junction of the primordium of the neural tube and the rest of the ectoderm gives rise, by way of a number of intermediate stages, to the ganglion cells of the spinal ganglia and the cerebral nerves, the ganglion cells of the autonomic nervous system, paraganglionic cells of the sympathetic and parasympathetic systems, Schwann and satellite cells, and the cells of the pia mater and the arachnoidea (Harvey and Burr, 1926; Stone, 1929; van Campenhout, 1930 ; Harrison, 1937 ; Rawles, 1947 ; Du Shane, 1948 ; Hörstadius, 1950). Since these cells often pass through comparable developments, it is not surprising that various neurogenic tumours often occur in combination, and that various grades of differentiation occur within one tumour. Many classifications of these tumours have been made; but the one put forward by Stout incorporates almost all of the important features of the others (Table I).

T A B L E I TUMOURS OF THE PERIPHERAL NERVOUS SYSTEM

\begin{tabular}{|c|c|c|}
\hline & Benign & Malignant \\
\hline $\begin{array}{l}\text { Tumours of the } \\
\text { peripheral nerves } \\
\text { Tumours of the } \\
\text { autonomous ner- } \\
\text { vous system } \\
\text { Tumours of the } \\
\text { paraganglionic } \\
\text { system }\end{array}$ & $\begin{array}{l}\text { Neurilemmoma } \\
\text { Neurofibroma } \\
\text { Ganglioneuroma } \\
\text { Pheochromocytoma } \\
\text { Paraganglioma }\end{array}$ & $\begin{array}{l}\text { Malignant Schwannoma } \\
\text { (neurogenic sa rcoma) } \\
\text { Sympatheticoblastoma } \\
\text { Partly differentiated } \\
\text { ganglioneuroma } \\
\text { Malignant pheochromo- } \\
\text { cytoma } \\
\text { Malignant paragan- } \\
\text { glioma }\end{array}$ \\
\hline
\end{tabular}




\section{MATERIAL AND METHODS}

The material comprised the data from 111 patients in whom a diagnosis of intrathoracic neurogenic tumour had been made. All the patients had received surgical treatment, so that the macroscopical and microscopical findings were available. The radiographs and the histological preparations were re-examined, and follow-up studies were carried out, in which all the surviving patients were included.

Some of the latter patients were examined postoperatively, and the remainder either filled in a questionnaire or were visited at home. The questionnaire included questions about complaints that might be due to a recurrence and whether chest radiographs had been taken recently. When the thorax had been examined either radiologically or fluoroscopically within the year preceding the follow-up, the patient was registered as having no recurrence.

For the patients who had reported themselves to be free of complaints suggestive of a recurrence of the tumour, it was assumed that there had been no recurrence. Although this did not completely preclude the inclusion of a patient with a recurrence in this group, the chance that this had occurred is, we submit, small.

For the deceased patients the cause of death was determined. Three had died as a result of the operation, one during surgery and two post-operatively.

Eight patients had died within a year of the operation as the result of a recurrence. Data for these were obtained from the specialists or general practitioners under whose care they had been.

For the patients who had died before the follow-up, either as the result of a disease unrelated to the neurogenic tumour or of an accident, it could be determined from information obtained from the family or general practitioner whether complaints had been present before death that might point to a recurrence. This was not the case for any of these patients. Consequently, it may be assumed for this group, too, that there had been no recurrence of the tumour (Table II).

\section{CLINICAL DATA}

Although neurogenic tumours occur at all ages, they occur predominantly in young adults. They may also be present at birth (Potter and Parrish, 1942 ; Gagnon, Dupal, and Katyk-Longtin, 1962 ; Mayo, 1963). The average age of the patients in our series was 35 years. The average ages of the patients with different neurogenic tumours varied: for those with a neurilemmoma it was 40 years; for those with a neurofibroma 37 years; for those with a malignant Schwannoma 33 years ; and for those with a neurogenic sarcoma 52 years. The average ages of patients who had a type of neurogenic tumour originating from the sympathetic nervous system were generally lower. For patients with a ganglioneuroma, the average age was 20 years. Sympatheticoblastoma was most frequently seen in children; in our material the average age for this tumour was 15 years.

The neurogenic tumour in our material occurred with a slightly higher frequency in women than in men ( 59 women; 52 men). This is in agreement with the data in the literature (Ackerman and Taylor, 1951 ; Ringertz and Lidholm, 1956 ; Carey et al., 1960 ; Diané, 1965 ; Dor et al., 1965).

Neurogenic tumours can occur anywhere where there is nerve tissue. Despite the fact that nerve tissue occurs everywhere in the thorax, these tumours are found predominantly at the site of the sympathetic chain and in the path of the spinal and intercostal nerves (Table III).

T A B L E I I

DATA OBTAINED FROM FOLLOW-UP

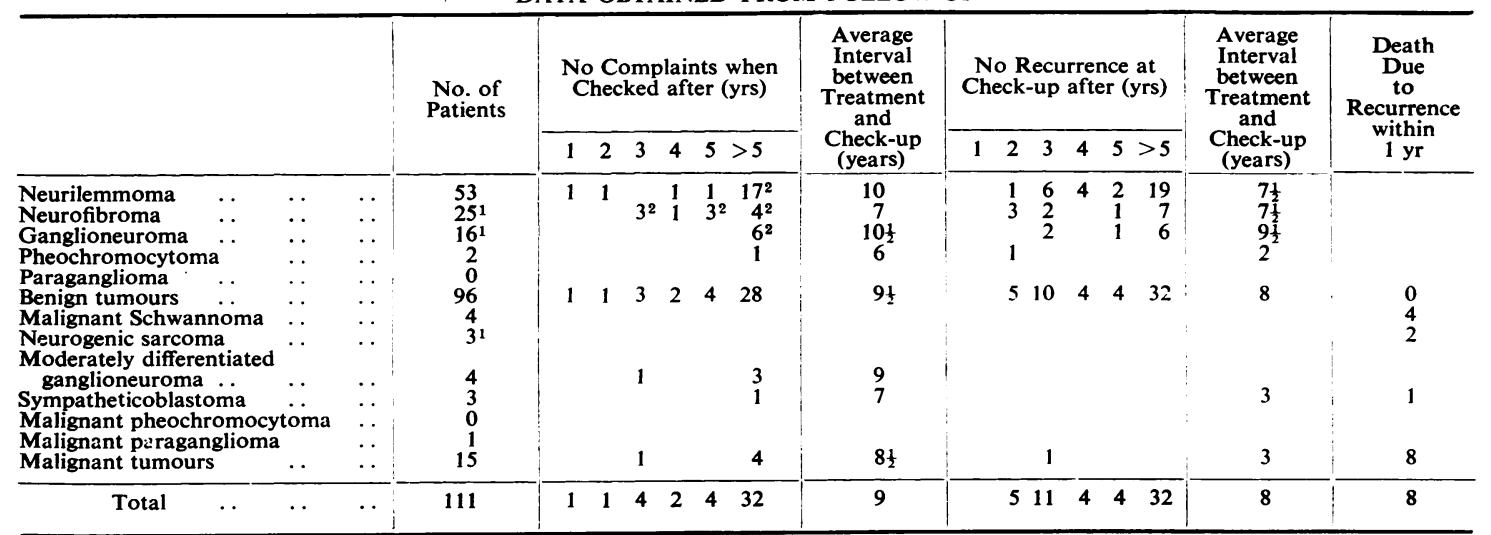

1 In this group one patient died as the result of the operation.

2 At the time of follow-up, these groups included one patient who had died without having had complaints suggesting a recurrence. 
T A B L E II I

SITE OF NEUROGENIC TUMOURS IN PRESENT STUDY

\begin{tabular}{|c|c|c|c|c|c|c|c|c|c|c|c|}
\hline & & & & & \multicolumn{2}{|c|}{ Side } & \multirow{2}{*}{$\begin{array}{c}\text { Posterior } \\
\text { Mediastinum }\end{array}$} & \multirow{2}{*}{$\begin{array}{l}\text { Intra- } \\
\text { pulmonary }\end{array}$} & \multirow{2}{*}{$\begin{array}{c}\text { Lateral } \\
\text { Thoracic } \\
\text { Wall }\end{array}$} & \multirow{2}{*}{$\underset{\text { Anterior }}{\text { Antiastinum }}$} & \multirow{2}{*}{ Total } \\
\hline & & & & & Right & Left & & & & & \\
\hline $\begin{array}{l}\text { Neurilemmoma } \\
\text { Neurofibroma } \\
\text { Ganglioneuroma } \\
\text { Pheochromocytoma } \\
\text { Benign tumours } \\
\text { Malignant Schwanno } \\
\text { Neurogenic sarcoma } \\
\text { Moderately different } \\
\text { Sympatheticoblastom } \\
\text { Malignant paragangl } \\
\text { Malignant tumours }\end{array}$ & $\begin{array}{l}\ldots \\
\cdots \\
\cdots \\
\cdots \\
\text { oma } \\
\text { tiated } 8 \\
\text { ma } \\
\text { lioma } \\
\ldots\end{array}$ & $\begin{array}{l}\ldots \\
\ldots \\
\ldots \\
\ldots \\
\ldots \\
\text { ganglio } \\
\ldots \\
\ldots\end{array}$ & $\begin{array}{l}\ldots \\
\ldots \\
\ldots \\
\ldots \\
\ldots \\
\text {. } \\
\ldots \\
\ldots \\
\ldots\end{array}$ & $\begin{array}{l}\cdots \\
\cdots \\
\cdots \\
\cdots \\
\cdots \\
\cdots \\
\cdots \\
\cdots\end{array}$ & $\begin{array}{r}35 \\
20 \\
7 \\
1 \\
63 \\
4 \\
2 \\
1 \\
\end{array}$ & $\begin{array}{r}18 \\
5 \\
9 \\
1 \\
33 \\
\\
1 \\
3 \\
3 \\
1 \\
8\end{array}$ & $\begin{array}{r}45 \\
20 \\
16 \\
2 \\
83 \\
3 \\
2 \\
4 \\
3 \\
12\end{array}$ & $\begin{array}{l}1 \\
1\end{array}$ & $\begin{array}{l}5 \\
1\end{array}$ & $\begin{array}{l}2 \\
3 \\
5 \\
1 \\
1 \\
2\end{array}$ & $\begin{array}{r}53 \\
25 \\
16 \\
2 \\
96 \\
4 \\
3 \\
4 \\
3 \\
1 \\
15\end{array}$ \\
\hline Total & .. & . & . & .. & 70 & 41 & 95 & 3 & 6 & 7 & 111 \\
\hline
\end{tabular}

Although few authors mention figures, according to the literature neurogenic tumours occur with almost equal frequency on the right and left sides (Ackerman and Taylor, 1951 ; Ringertz and Lidholm, 1956). In our material there was a predilection for the right side (70 on the right side, 41 on the left). This predilection was more strongly expressed in the benign tumours (Table III).

When the neurogenic tumour originated from the sympathetic chain or the spinal nerve, the classic localization in the sulcus costovertebralis was found: this localization was seen in 95 of our patients. The upper part of the posterior mediastinum was more frequently the origin of these tumours than the lower.

With a dorsal localization the tumour may acquire an hourglass shape consisting of an intrathoracic and an intraspinal (sometimes intradural) portion. Intraspinal extension was seen at surgery in nine cases, and five showed a stem-like extension reaching as far as the intervertebral foramen. In the pathway of the intercostal nerves a neurogenic tumour may lie more laterally in the thorax ; this was the case in six patients.

In the anterior mediastinum the tumours were less frequent than in the posterior mediastinum. In this region the lesions can originate from either the phrenic or vagus nerves. In addition to the three patients in whom the tumour arose from the phrenic or vagus nerves, a localization in the anterior mediastinum was found in four others. In two of these a tumour was removed from the intrathoracic portion of the vagus nerve, and in one from the phrenic nerve. These are unusual sites. Tumours arising from the small nerve branches along the bronchial tree may result in an intrapulmonary mass; this occurred in three patients in our series.

Neurogenic tumours are usually found by chance in mass chest surveys or on routine examinations for other complaints. Of our 111 patients the tumour was found by chance in 94,77 of these during a mass survey and 15 on a routine chest radiograph. Malignant tumours were found by chance in seven patients, although, when a detailed history was taken, five were found to have symptoms. In the group with benign tumours the lesion was found by chance in 87 . Of these, two were found to have symptoms. The symptoms associated with neurogenic tumours were varied, and were often the result of pressure caused by the tumour. The most frequent complaint was pain, which varied in intensity from a vague sensation of pressure to radicular pain. Dyspnoea and coughing may also occur, and a positive Horner's syndrome was found with some tumours in the upper mediastinum.

Neurological signs were seldom evident, probably because of a certain selection: patients with neurological complaints were usually referred to the neuro'ogist.

For the malignant tumours, general complaints were frequently found in the form of fever and a feeling of being ill. Of the two patients with a

\section{T A B L E I V}

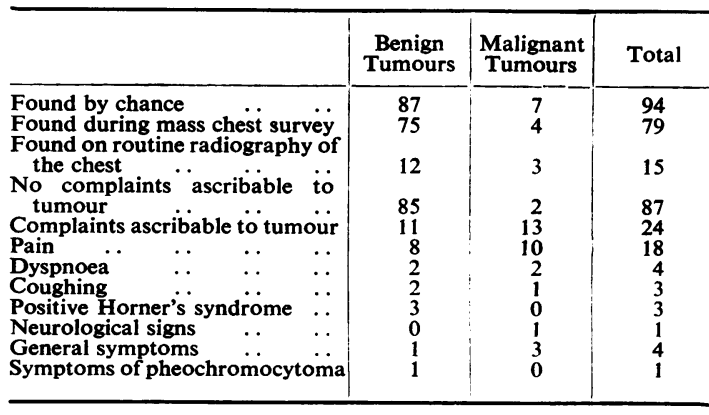


pheochromocytoma, one showed a complex of symptoms due to the biological activity of this neoplasm (Table IV).

\section{RADIOLOGICAL FINDINGS}

Radiography is important in the diagnosis of neurogenic tumours (Buschmann and Willich, 1965 ; Le Brigand, Merlier, Wapler, Verley, and Carpentier, 1965). A characteristic picture was generally found. On the postero-anterior radiograph of the thorax the classic case showed a paramediastinal, usually homogeneous, radiopacity with sharply defined borders. Medially, this shadow extended into that of the mediastinum. The shape of the shadow was usually roughly round. The borders occasionally showed a polycyclic appearance. On the lateral radiographs the anomaly was seen to lie dorsally in the thoracic cavity. Large tumours were partially, and small tumours totally, projected towards the spinal column. In neoplasms located high in the pleural dome the upper limit of the lesion often blended into the shadow of the soft tissue of the neck (Figs 1 and 2).

The size of the tumour varied from the dimensions of a marble to a very large mass occupying the entire thorax (Weiss and Koebelé, 1955; Liaras, Houel, and Aprosio, 1956 ; Lasley, 1957). Tomography in the postero-anterior and lateral directions made it possible to determine the position of the tumour exactly with respect to the surrounding tissue. It also revealed that the localization is not actually mediastinal but in the sulcus costovertebralis.

The structure of the tumour can also be seen more clearly on tomograms. In some it was found to show lacunae originating from cystic degeneration, which could progress so far that a cyst seemed to be present. But histological examination showed that the wall of the 'cyst' was formed by tissue belonging to the lesion itself.

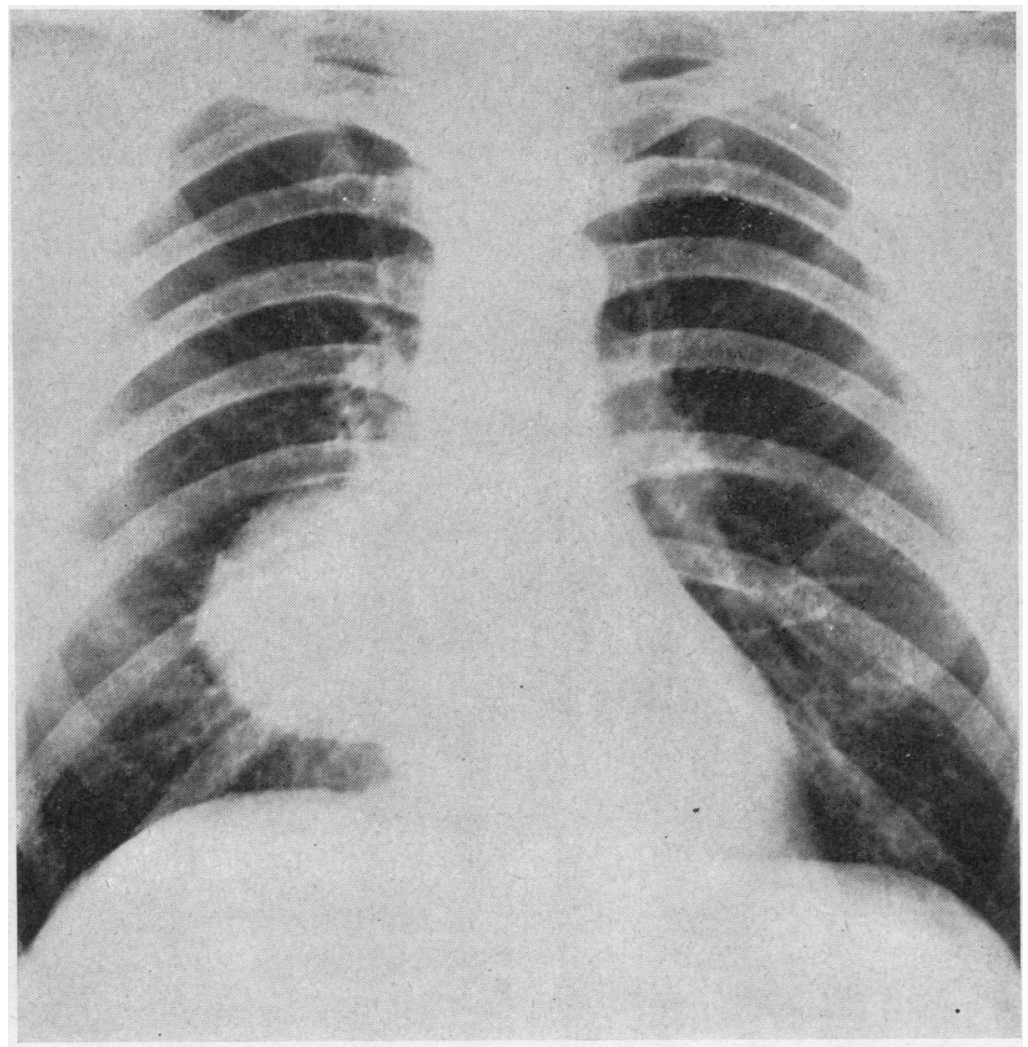

FIG. 1. Postero-anterior radiograph of the thorax. Paramediastinally located. round, homogeneous radiopacity with sharply defined borders. 


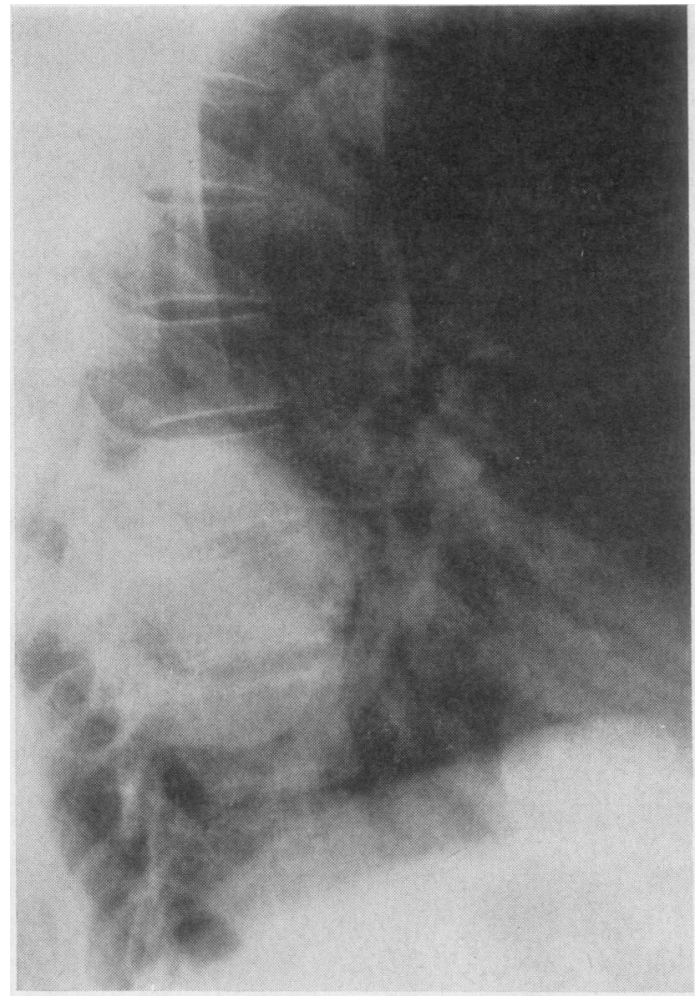

FIG. 2. Lateral radiograph. The homogeneous, sharply defined shadow is partially projected on the spinal column.

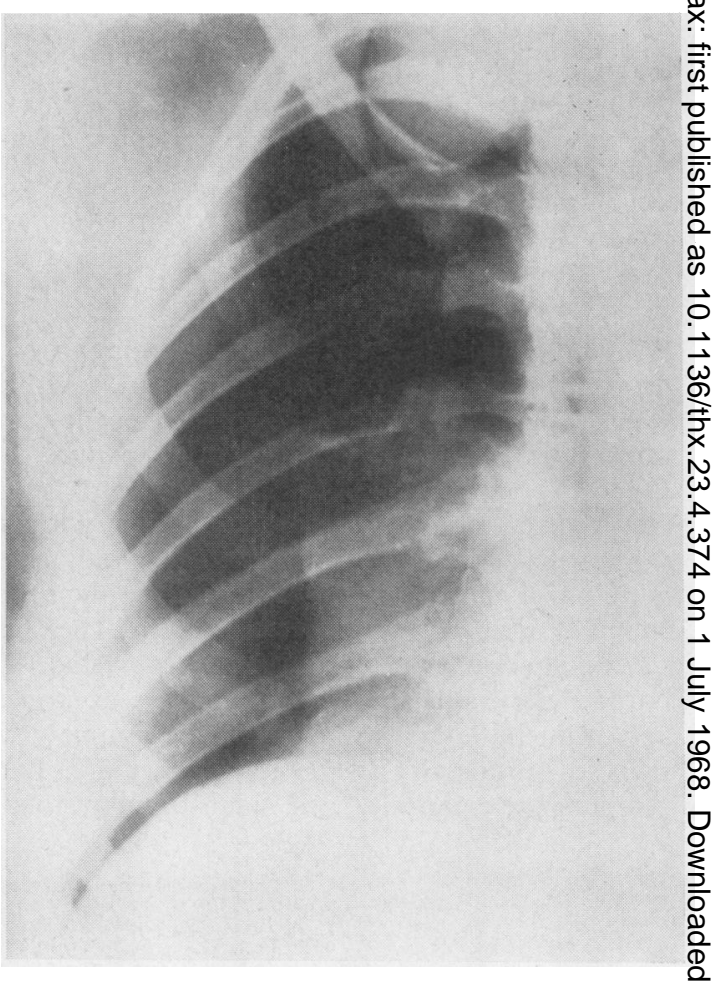

FIG. 3. Radiograph after application of a diagnostic pneumothorax. The radiopacity is not attached to the collapsed lung. 
Calcification also occurred (Bendixen and Lamb, 1926 ; Bergström, 1937 ; Parsons and Platt, 1940 ; Chandler and Norcross, 1940 ; Potter and Parish, 1942). These calcifications were regarded as regressive changes (Startz and Abrams, 1938; Wyatt and Farber, 1941 ; Mandeville, 1949). Usually, granular calcifications were seen more or less centrally in the tumour mass (Hastings, Pollock, and Snyder, 1961), but some showed a shell-shaped extension of the calcification (Buschmann and Willich, 1965). Calcification was infrequent in the intrathoracically localized tumours (Hansman and Girdany, 1957 ; King, Storaasli, and Bolande, 1961). An extrapulmonary localization of the tumour could be demonstrated radiographically after application of a diagnostic pneumothorax. The usual observation was a collapsed lung to which the tumour was not attached (Fig. 3).

We induced a diagnostic pneumothorax in 49 cases ; in 46 of these an extrapulmonary localization could be demonstrated and in three others this was probable.

Skeletal radiographs of the thorax were important for the demonstration of pathological changes in the spinal column and ribs. With an intraspinal extension of the lesion, enlargement of an intervertebral foramen could sometimes be found (Fig. 4).

If the picture was difficult to interpret, tomography of the spinal column was useful. According to Ackerman and Taylor (1951), erosion of the ribs or vertebrae may be an indication of malignancy. But very extensive vertebral changes may result in scoliosis; this finding has been reported by Bobretzkaja and Heinismann (1935), Ackerman and Taylor (1951), Ganz (1954), and Razemon and Ribet (1965). According to Love and Dodge (1952), the enlargement of the intervertebral foramen is the most important sign of intra-spinal extension. They found this enlargement on 40 occasions in 60 hourglass tumours. In our material an enlargement of an intervertebral foramen was found on the radiograph in two cases; in one 'erosion' of a rib was observed. ${ }^{1}$

Radiologically, investigations such as myelography may contribute to the determination of the extension of an intrathoracic tumour into the vertebral canal. In some cases angiography, or radiography after the application of a pneumoperitoneum, may contribute to the differential diagnosis.

\footnotetext{
${ }^{1}$ Most thoracic surgeons have found 'splaying' of the adjacent ribs to be common.-Editor.
}

\section{THE DIFFERENTIAL DIAGNOSIS}

A large number of anomalies occur in the thorax and are sometimes difficult to distinguish from a neurogenic tumour. Intrapulmonary lesions such as hamartochondromas, fibromas, myxomas, lipomas, carcinomas, and metastases were considered when the localization of the neoplasm was mediodorsal. In most of these cases a diagnostic pneumothorax demonstrated that the localization was not extrapulmonary. Mediodorsally localized benign pleural tumours, such as fibromas and mesotheliofibromas, seldom gave the impression of a neurogenic tumour. The same is true for the malignant pleural tumours. Cystic lesions, like bronchial cysts and ecchinococcal cysts, also required consideration. More frequently the distinction concerned lesions localized in the sulcus costovertebralis or in the posterior mediastinum. For chondromas, osteochondromas, and chondrosarcomas arising from the ribs or vertebrae, and for meningocoeles and tuberculous cold abscesses in Pott's disease, a radiological examination usually provided sufficient information, because these lesions almost always involved characteristic changes in the ribs or vertebrae.

Para-oesophageal cysts, such as gastrogenic, enterogenic, and bronchial cysts, usually lay anteriorly. Thoracic struma also entered into the differential diagnosis. Difficulties were sometimes encountered, due to pathological changes in the heart or large blood-vessels (e.g., an aneurysm of the aorta behind an isthmus stenosis and in an occasional case of diaphragmatic hernia); an intrathoracically situated lobe of the liver or spleen could give the impression of a neurogenic tumour.

With the above-mentioned diagnostic methods. among which radiology was the most important, a diagnosis could be made only with probability. For a definite diagnosis, histological examination of a biopsy sample or thoracoscopy was required.

PUNCTURE BIOPSY Because the final diagnosis requires a histological description of a tumour with a specific structure, we believe that a biopsy is sometimes useful. This can be done by puncture of the tumour. This sample consists of only a small portion of the tumour and may not be representative of the whole.

In our material a puncture biopsy was carried out in 35 cases. In 16 of these tumour tissue was not obtained and no diagnosis could be made. In nine, the pathologist could only establish the presence of a benign or malignant tumour ; in one the conclusion was incorrect. In 10 a diagnosis was 
T A B L E V

DIAGNOSES BASED ON PUNCTURE BIOPSIES

\begin{tabular}{|c|c|c|c|c|c|c|c|c|c|c|c|c|}
\hline \multirow[b]{2}{*}{$\begin{array}{l}\text { Diagnosis Based on } \\
\text { Post-operative } \\
\text { Histology }\end{array}$} & \multicolumn{11}{|c|}{ Diagnosis Based on Tumour Puncture } & . \\
\hline & $\begin{array}{l}\text { Neuri- } \\
\text { lem- } \\
\text { moma }\end{array}$ & $\begin{array}{l}\text { Neuro- } \\
\text { fibroma }\end{array}$ & $\begin{array}{l}\text { Ganglio- } \\
\text { neuroma }\end{array}$ & $\begin{array}{c}\text { Malig- } \\
\text { nant } \\
\text { Schwan- } \\
\text { noma }\end{array}$ & $\begin{array}{l}\text { Neuro- } \\
\text { genic } \\
\text { Sar- } \\
\text { coma }\end{array}$ & $\begin{array}{l}\text { Partially } \\
\text { Differen- } \\
\text { tiated } \\
\text { Ganglio- } \\
\text { neuroma }\end{array}$ & $\begin{array}{l}\text { Sympatheti- } \\
\text { coblastoma }\end{array}$ & $\begin{array}{l}\text { Malig- } \\
\text { nant } \\
\text { Paragan- } \\
\text { glioma }\end{array}$ & $\begin{array}{l}\text { Benign } \\
\text { Tumour }\end{array}$ & \begin{tabular}{|c|} 
Malig- \\
nant \\
Tumour
\end{tabular} & $\begin{array}{l}\text { No } \\
\text { Diag- } \\
\text { nosis }\end{array}$ & Total \\
\hline $\begin{array}{l}\text { Neurilemmoma } \\
\text { Neurofibroma } \\
\text { Ganglioneuroma } \ldots \\
\text { Malignant Schwannoma } \\
\text { Neurogenic sarcoma } \\
\text { Partially differentiated } \\
\text { ganglioneuroma . } \\
\text { Sympatbeticoblastoma } \\
\text { Malignant } \\
\text { paraganglioma }\end{array}$ & $\begin{array}{l}4 \\
1\end{array}$ & $\begin{array}{l}1 \\
3\end{array}$ & & & 1 & & & & $\begin{array}{l}3 \\
3\end{array}$ & 1 & $\begin{array}{l}8 \\
2 \\
2 \\
1 \\
1 \\
1 \\
1\end{array}$ & $\begin{array}{r}16 \\
8 \\
2 \\
2 \\
3 \\
\\
2 \\
1\end{array}$ \\
\hline Total & 5 & 4 & & & 1 & & & & 7 & 2 & 16 & 35 \\
\hline
\end{tabular}

made from the puncture material ; in eight cases this diagnosis proved to be correct, in one case a neurilemmoma was mistakenly diagnosed as a neurofibroma, and in one a malignant Schwannoma was diagnosed as a neurilemmoma (Table V).

THORACOSCOPY Thoracoscopy after application of a pneumothorax can sometimes provide valuable information about the morphological aspects of the tumour. In the classic case, a yellowish-white subpleurally localized mass, sometimes showing a cystic appearance, was found in the sulcus costovertebralis. A biopsy or puncture sample taken through the thoracoscope has been valuable. An advantage over percutaneous puncture was that a more suitable portion of the mass could be chosen for sampling. Increasing use is being made of this diagnostic procedure in our hospital. In seven of the nine cases with neurogenic tumours in which thoracoscopy was performed, a definitive diagnosis was made in this way.

For pheochromocytoma and tumours of the sympathetic nervous system, such as sympatheticoblastoma and ganglioneuroma, determination of the catecholamines in the urine was used for reaching a diagnosis (Jacob, 1962 ; Huebner and Reed, 1963 ; Mathey, Lemoine, Schweisguth, Buhuon, and Labrosse, 1965).

\section{THERAPY}

Neurogenic tumours can be treated by surgical removal and, in some cases, irradiation or chemotherapy.

The mortality of surgical removal of neurogenic tumours was low when the mass was not so large that it caused functional disturbances. In our material one patient died during surgery and two shortly after the operation. In the first, death wase due to a number of factors: it was a large tumoub in a patient of advanced age who also had cardia $\dot{\varepsilon}$ anomalies. Of the two patients who died shortlye after the operation, death was caused in one bys uraemia due to transfusion from an incompatible blood group and in the other by haemorrhagico diathesis of unknown origin. $3 \%$.

In 111 patients the mortality rate was just below $\overrightarrow{\overrightarrow{0}}$

The post-operative complications associated with intrathoracic neurogenic tumours varied, but their frequency was low. In the literature mention is made of haemothorax, atelectasis, chylothorax disturbance of the brachial plexus, and a positive Horner's syndrome (Binet, Lemoine, Galey, and Mathey, 1965). In our material a pleural exudate was found in four patients, requiring one or more aspirations. One patient developed empyema postoperatively, and one had a haemothorax after surgery requiring a second thoracotomy. One patient, in whom a neurogenic tumour with an intraspinal extension was removed by thoraco $N$ tomy, developed a transverse lesion of the cord probably as the result of pressure from a remnanf of the tumour in the vertebral canal. This trans $\omega$ verse lesion persisted after laminectomy to remove the rest of the tumour. Temporary paresis of the brachial plexus was observed post-operatively in? two patients.

There were four reasons for surgical treatment $: \frac{7}{0}$

1. THE RISK OF MALIGNANCY In our material the diagnosis of malignancy was made in 15 cases, which amounted to almost $14 \%$. Bariéty ance Coury (1958) report 20\% malignant tumours im 790 intrathoracic neurogenic tumours collected 
from the literature. When a definitive diagnosis was lacking a chance of malignancy of the order of 14 to $20 \%$ was taken into account.

2. INCREASE IN THE SIZE OF THE TUMOUR This increased the risk of surgery. We encountered this situation when a patient died during the operation to remove a very large mass.

3. THE CHANCE OF MALIGNANT DEgENERATION It is difficult to find exact data on this point in the literature. Although neurilemmoma is said almost never to become malignant, malignant degeneration has been reported for neurofibromas (Harrington, 1934 ; Ganz, 1954 ; Thorsrud, 1960). The percentage of neurofibromas that become malignant cannot be estimated, but the possibility should be kept in mind. The chance of malignant degeneration is also difficult to assess because ganglioneuroma also occurs in combination with sympatheticoblastoma. In these partially differentiated ganglioneuromas a biopsy sample may contain only ganglioneuroma tissue, resulting in an incorrect diagnosis.

4. DANGer OF PERMANENT DAMAge TO NERVE SIRUCTURES IN SPINAL CANAL WITH INTRASPINAL EXTENSION OF TUMOUR All forms of neurogenic tumour can extend intraspinally. One of our patients developed a transverse lesion as the result of a tumour remnant left behind in the vertebral canal after excision of the main mass. An intraspinal extension was found in nine cases, and in five there was extension as far as the intervertebral foramen.

A special therapeutic problem arose with respect to patients suffering from neurofibromatosis (von Recklinghausen's disease) with an intrathoracically localized tumour. This was usually a neurofibroma. According to the literature, the chance of malignant degeneration is great in these cases. Various authors calculate the chance of malignant degeneration in this group to be of the order of $10 \%$ (Hosoi, 1931 ; Stout, 1935 ; Holt and Wright, 1948 ; Preston, Walsh, and Clarke, 1952). Surgical treatment has been thought to increase the chance of malignant degeneration (Hosoi, 1931 ; Clément, Delon, and Monod, 1942 ; Herrmann, 1950 ; Monod, Paillas, Pesle, and Labeguerie, 1951 ; Cayla, Thenot, and Coste, 1963), but this is not confirmed by Thorsrud (1960) and d'Agostino, Soule, and Miller (1963). It seems likely that the best policy with respect to von Recklinghausen's disease is to reserve radical therapy and to restrict surgery to cases in which there are complaints demanding removal, and to cases in which the tumour shows rapid growth. Our material included only one case of this type; no recurrence was found at a follow-up examination two years after treatment.

In our patients a postero-lateral thoracotomy was always performed to remove the tumour. This incision was found to give good access. When an intraspinal extension was present, it was usually possible to remove this part of the tumour by the same route. When this was not possible, the rest of the tumour had to be removed by laminectomy at the same operation or shortly thereafter. Laminectomy was required on four occasions. In the other five patients who had an intraspinal extension this could be removed at thoracotomy. This was also the case for the five patients in whom the tumour extended into the intervertebral foramen. When the intraspinal extension has led to symptoms, it is preferable, according to Ballivet (1949), Merlier (1951), and Love and Dodge (1952), to start with a laminectomy and remove the intrathoracic portion of the tumour later.

In 96 of our patients a benign tumour was removed surgically. Two of these died post-operatively due to surgical complications. The follow-up showed that five patients had died of unrelated causes, without evidence of recurrence. In the 89 who were still alive at the time of the follow-up, there had been no complaints suggestive of recurrence. Ackerman and Taylor (1951), Ringertz and Lidholm (1956) and Carey et al. (1960) also report a very low percentage of recurrence after surgery for benign neurogenic lesions.

Patients with a sympatheticoblastoma presented a special problem of treatment. The evaluation of the results of treatment in these is complicated by the spontaneous recovery that sometimes occurs (Cushing and Wolbach, 1927; Ackerman and Taylor, 1951 ; Koop, Kiesewetter, and Horn, 1955 ; Bodian, 1959; Eyre-Brook and Hewer, 1962 ; Oberman, 1963 ; Swaen, 1966). The chance of spontaneous recovery is greater the younger the patient, and amounts to about 1 to $2 \%$ for children under 1 year of age (Hastings et al., 1961). The explanation for the phenomenon is not clear, and may not always be the same. In certain cases it may be assumed that the tumour has become more mature and that a ganglioneuroma has developed from the sympatheticoblastoma (Cushing and Wolbach, 1927; Farber, 1940 ; Wittenborg, 1950 ; Fox, Davidson, and Thomas, 1959; Phillips, 1953; Kissane and Ackerman, 1955 ; Eyre-Brook and Hewer, 1962 : Swaen, 1966). In other cases it seems more prob- 
able that the tumour has grown too rapidly for its blood supply, as a result of which necrosis has developed (Farber, 1940 ; Bodian, 1959).

It is generally accepted that the prognosis of the intrathoracic sympatheticoblastoma is slightly better than that of the abdominal forms (Horn, Koop, and Kiesewetter, 1956 ; Gross, Farber, and Martin, 1959 ; Bodian, 1959 ; Hastings et al., 1961 ; Buschmann and Willich, 1965). Sutow (1958) found no difference in prognosis between the abdominal and the other localizations. In infants the chance of a cure is greater than in older children (Horn et al., 1956; Gross et al., 1959 ; Dargeon, 1962 ; Hastings et al., 1961 ; Vinik and Altman, 1966).

THE CHOICE OF TREATMENT With respect to therapy, three possible courses, or combinations of them, are available, namely-surgical removal of the tumour, irradiation, or chemotherapy.

1. Surgical treatment of sympatheticoblastomas was often difficult because the infiltrative growth of the tumour made radical removal difficult. In general, the most radical treatment possible was applied (Wittenborg, 1950 ; Gross et al., 1959 ; King et al., 1961 ; Hastings et al., 1961). When radical excision was impossible, it remained important to remove as much of the tumour as possible. Poore, Dockerty, Kennedy, and Walters (1951) found a survival percentage of $10 \%$ for therapy consisting solely of a biopsy ; for the best possible excision of the tumour this value rose to $50 \%$. A similar observation has been reported by Koop et al. (1955).

2. Irradiation was given in the form of roentgen therapy after surgery. Pre-operative irradiation is recommended by Buschmann and Willich (1965), but Gross et al. (1959) and Hastings et al. (1961) advise against it.

Wittenborg (1950) used a tumour dose of 800 to $1,200 \mathrm{r}$ over 10 to 14 days, followed within three months by a second series with the same dosage. Irradiation can be started on the day of the operation (Gross et al., 1959). The danger of postoperative bleeding was not increased by this treatment. Buschmann and Willich (1965) advised a higher dose ; they used 2,000 to $3,000 \mathrm{r}$ with radical resection and 4,000 to $5,000 \mathrm{r}$ with incomplete resection.

Irradiation of metastases is generally considered to be useful, although it has been found that better results are to be expected for metastases in soft tissue (liver, etc.) than for skeletal metastases (Wittenborg, 1950 ; Poore et al., 1951 ; Uhlmann and von Essen, 1955; Seaman and Eagleton,
1957 ; Hastings et al., 1961). Cases of skeletal $\stackrel{\overrightarrow{\bar{\omega}}}{\frac{\overrightarrow{5}}{\sigma}}$ metastases with recovery are known. According to Buschmann and Willich (1965), 16 such have been $\frac{\bar{\sigma}}{2}$ reported in the literature.

3. Chemotherapy has been reported to give reasonably good results (Buschmann and Willich, 1965). Satisfactory results have been obtained, for $\vec{\circ}$ instance, with cyclophosphamide (Sweeney, $\overrightarrow{\vec{\omega}}$ Trittle, Etteldorf, and Whittington, $1962 ; \stackrel{\omega}{\circ}$ Gürrson, 1963 ; Weber, 1964 ; Sawyers et al., 1964 ; Thurman, Fernbach, and Sullivan, 1964).

A somewhat unusual place is occupied by treat- $\omega$ ment with vitamin $B_{12}$. The first publications on $\frac{\vec{\omega}}{\vec{\omega}}$ this subject by Bodian $(1959 ; 1963)$ seemed en- $-\vec{A}$ couraging. Bodian had treated 74 children, mosto of whom had extensive metastases, with high doses of vitamin $B_{12}(1 \mathrm{mg}$. every 2 days for $2 c$ years ; after $19571 \mathrm{mg}$. per $7 \mathrm{~kg}$. body weight for 3 years). He reported 33 deaths in this group. $\overrightarrow{0}$ Twenty-eight children had been followed for more than 2 years. The explanation of the effect of vitamin $\mathbf{B}_{12}$ has not been clarified but could be dueo to a growth-promoting effect causing the tumour to exceed the capacity of its blood supply, result-o ing in necrosis, or to an influence of the vitamin by which a ganglioneuroma develops from $a \stackrel{\Phi}{\circ}$ sympatheticoblastoma. Phillips (1953), Fisher $\overrightarrow{0}$ (1958), Isaacs, Medalie, and Politzer (1959), and 3 Knudson and Amromin (1966) also report good results with this treatment. A questionnaire survey to collect the results obtained by a group of American surgeons with vitamin $\mathbf{B}_{12}$ therapy, which concerned 103 patients, yielded no conclu-x sive results (Sawitsky and Desposito, 1965). Consequently, a final opinion on treatment with vitamin $B_{12}$ cannot be given, but, because even large dosages of that vitamin do not have a toxic effect, it would seem advisable to apply this treat-은 ment consistently in combination with surgery and irradiation.

Our material included three cases of sympathet icoblastoma and four of moderately differentiated ganglioneuroma. These patients were treated surgically: a macroscopically radical operation $\omega$ could be performed in seven. High dosages of vitamin $B_{12}$ were also administered $(2 \mathrm{mg}$. everyo other day). The four patients with moderatelyo differentiated ganglioneuroma had no recurrence after $4,7,10$, and 17 years. Of the three patients with a sympatheticoblastoma, one died within aे short time; the other two showed no signs of? recurrence after 3 and 7 years.

Malignant Schwannoma and neurogenic sar coma have a poor prognosis. The treatments of choice are surgery (although a macroscopicallyo 
radical operation is often impossible) and irradiation. Our material included seven of these malignant neoplasms. These patients were treated with surgery and post-operative irradiation; one of them died during the operation. The follow-up showed that all the others had died of a recurrence within one year of the operation. These findings agree with the data in the literature: Ackerman and Taylor (1951), Ringertz and Lidholm (1956), Poole and Deeley (1963), Heard (1963), Cayla et al. (1963), and d'Agostino et al. (1963) also report a high percentage of recurrence for these tumours.

\section{REFERENCES}

Ackerman, L. V., and Taylor, F. H. (1951). Neurogenous tumors within the thorax. Cancer (Philad.), 4, 669.

d'Agostino, A. N., Soule, E. H., and Miller, R. H. (1963). Sarcomas of the peripheral nerves and somatic soft tissues associated with multiple neurofibromatosis (von Recklinghausen's disease). Ibid., 16, 1015.

Ballivet, J. (1949). Volumineux neurinome en sablier intrarachidien et intrathoracique. Rev. neurol., 81, 66.

Bariéty, M., and Coury, C. (1958). Le Médiastin et sa Pathologie. Masson, Paris.

Bendixen, P. A., and Lamb, F. H. (1926). Malignant tumors of the adrenal in children. J. Lab. clin. Med., 12, 130.

Bergstrëm, V. W. (1937). Congenital neuroblastoma of the adrenal. Amer. J. clin. Path., 7, 516.

Binet, J. P., Lemoine, G., Galey, J. J., and Mathey, J. (1965). Les tumeurs nerveuses du thorax chez l'enfant; étude de 61 cas.
Ann. (hir. thorac. Cardiovasc., 4, p. C. 887 , C.T. 383 .

Blades, B. (1946). Mediastinal tumors. Ann. Surg., 123, 749.

Bobretzkaja, W., and Heinismann, J. I. (1935). Beiträge zur Röntgendiagnostik der mediastinalen Neurinome. Fortschr. Röntgenstr., 52, 191.

Bodian, M. (1959). Neuroblastoma. Pediat. Clin. N. Amer., 6, 449.

- (1963). Neuroblastoma; an evaluation of its natural history and the effects of therapy, with particular reference to treatment by massive doses of vitamin B12. Arch. Dis. Childh., 38, 606.

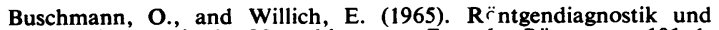
Radiotherapie der Neuroblastoma. Fortschr. Röntgenstr., 101, 1.

Campenhout, E. van $\left(193^{\wedge}\right)$. Historical survey of the development of the sympathetic nervous system.

Carey, L. S., Ellis, F. H., Good, C. A., and Woolner, L. B. (1960). Neurogenic tumors of the mediastinum: a clinicopathologic study. Amer. J. Roentgenol., 84, 189.

Cayla, J., Thenot, A., and Coste, F. (1963). Neuro-fibromatose de Recklinghausen et dégénérescence maligne. Rev. Rhum., 30, 188.

Chandler, F. A., and Norcross, J. R. (1940). Sympathicoblastoma. J. Amer. med. Ass., 114, 112.

Clément, R., Delon, J., and Monod, O. (1942). Ganglionevrome intrathoracique opéré avec succès par voie extrapleurale. Arch. frans. Pédiat., 1, 34.

Cushing, H., and Wolbach, S. B. (1927). The transformation of a malignant paravertebral sympathicoblastoma into a benign ganglioneuroma. Amer. J. Path., 3, 203.

Dargeon, H. W. (1962). Neuroblastoma. J. Pediat., 61, 456.

Diané, C. (1965). Note à propos de 37 neurinomes thoraciques. Ann. chir. thorac. Cardiovasc., 4 , p. C. 849 , C.T. 345.

Dor, J., Houel, J., Reboud, E., Longefait, H., and Malméjac, C. (1965). Résultats éloignés des tumeurs nerveuses du médiastin. (1965). Résultats éloignés des tumeurs nerveuses du
Ann. Chir. thorac. cardiovasc., 4, p. C. 882, C.T. 379.

Du Shane, G. P. (1948). The development of the pigment cells in vertebrates, In The Biology of Melanomas. [N.Y. Acad. Sci., Vol. 4. Special publication.]

Eyre-Brook, A. L., and Hewer, T. F. (1962). Spontaneous disappearance of neuroblastoma with maturation to ganglioneuroma. $J$. Bone Jt Surg., 44B, 886.

Farber, S. (1940). Neuroblastoma. Amer. J. Dis. Child., 60, 749.

Fisher, O. D. (1958). Thoracic neuroblastoma, treated with vitamin B12. Proc. roy. Soc. Med., 51, 742.

Fox, F., Davidson, J., and Thomas, L. B. (1959). Maturation of sympathicoblastoma into ganglioneuroma: report of two patients with 20 - and 46-year survivals respectively. Cancer, 12, 108.
Gagnon, J., Dupal, M. F., and Katyk-Longtin, N. (1962). Anomalies chromosomiques dans une observation de sympathome congénital. Rev. canad. Biol., 21, 145.

Ganz, P. (1954). Die Nervengeschwülste des Thoraxinnenraumes. Chirurg, 25, 58.

Gross, R. E., Farber, S., and Martin, L. W. (1959). Neuroblastoma sympatheticum. Pediatrics, 23, 1179.

Hansman, C. F., and Girdany, B. R. (1957). The roentgenographic findings associated with neuroblastoma. J. Pediat., 51, 621.

Harrington, S. W. (1934). Surgical treatment in fourteen cases of mediastinal or intrathoracic perineurial fibroblastoma. $J$. thorac. Surg., 3, 590 .

Harrison, R. G. (1937). Die Neuralleiste. Anat. Anz. Erg., 85, 4.

Harvey, S. C., and Burr, H. S. (1926). The development of the meninges. Arch. Neurol. Psychiat. (Chic.), 15, 545.

Hastings, N., Pollock, W. F., and Snyder, W., Jr. (1961). Retroperitoneal tumors in infants and children. Arch. Surg., 82, 950.

Heard, G. (1963). Malignant disease in von Recklinghausen's neurofibromatosis. Proc. roy. Soc. Med., 56, 502.

Herrmann, J. (1950). Sarcomatous transformation in multiple neurofibromatosis. Ann. Surg., 131, 206.

Holt, J. F., and Wright, E. M. (1948). The radiologic features of neurofibromatosis. Radiology, 51, 647 .

Horn, R. C., Koop, C. E., and Kiesewetter, W. B. (1956). Neuroblastoma in childhood, Clinicopathologic study of forty-four cases. Lab. Invest., 5, 106.

Hosoi, K. (1931). Multiple neurofibromatosis (von Recklinghausen's disease), with special reference to malignant transformation. Arch. Surg., 22, 258.

Hërstadius, S. (1950). The Neural Crest. Oxford University Press, London.

Huebner, G. D., and Reed, P. A. (1963). Secreting tumors of chromaffin tissue. Ann. Surg., 158, 216.

Isaacs, H., Medalie, M., and Politzer, W. M. (1959). Noradrenalinesecreting neuroblastoma. Brit. med. J., 1, 401.

Jacob, N. H. (1962). Relationship of phenolic acid excretion to tumors of neural crest origin. Texas St. J. Med., 58, 893 .

Jaubert de Beaujeu, M., and Maret, G. (1965). Les tumeurs nerveuses intrathoraciques chez l'enfant. Ann. Clin. thorac. cardiovasc., 4. p. C. 893 , C.T. 389.

Kent, E. M., Blades, B. C., Valle, A. R., and Graham, E. A. (1944). Intrathoracic neurogenic tumors. J. thorac. Surg., 13, 116.

King, R. L., Storaasli, J. P., and Bolande, R. P. (1961). Neuroblastoma: Review of 28 cases and presentation of two cases with metastases and long survival. Amer. J. Roentgenol., 85, 733.

Kissane, J. M., and Ackerman, L. V. (1955). Maturation of tumours of the sympathetic nervous system. J. Fac. Radiol. (Lond.), 7, 109.

Knudson, A. G., and Amromin, G. D. (1966). Neuroblastoma and ganglioneuroma in a child with multiple neurofibromatosis. Cancer, 19, 1032.

Koop, C. E., Kiesewetter, W. B., and Horn, R. C. (1955). Neuroblastoma in childhood. Surgery, 38, 272.

Lasley, C. H. (1957). Excision of massive ganglioneuroma of mediastinum. Dis. Chest, 31, 709.

Le Brigand, H., Merlier, M., Wapler, C., Verley, J., and Carpentier, A. (1965). Neurinomes et faux neuronomes de médiastin. Ann. Chir. thorac. cardiovasc., 4, p. C. 854, C.T. 350.

Liaras, Houel, J., and Aprosio (1956). Neurinome intrathoracique géant. Afr. franc. chir., 14, 432.

Love, J. Grafton, and Dodge, H. W. (1952). Dumbbell (hourglass) neurofibromas affecting the spinal cord. Surg. Gynec. Obstet., 94,161 .

Mandeville, F. B. (1949). Calcification in sympathoblastoma (neuroblastoma). Radiology, 53, 403.

Mathey, J., Lemoine, G., Schweisguth, O., Buhuon, G., and Labrosse, E. (1965). Importance du dosage des catécholamines dans les tumeurs neurogènes intrathoraciques de l'enfant. Ann. Clin. thorac. cardiovasc., 4 , p. C. 884 , C.T. 381 .

Mayo, P. (1963). Intrathoracic neuroblastoma in a newborn infant. J. thorac. cardiovasc. Surg., 45, 720.

Merlier, M. (1951). Neurinomes intrathoraciques. Poumon, 7, 331.

Meyer, K. K., and Ochsner, J. L. (1966). Intrathoracic neurogenic tumors. Surg. Clin. N. Amer., 46, 1427.

Monod, O., Paillas, Pesle, and Labeguerie (1951). La dégénerescence maligne de la neurofibromatose de Recklinghausen après intervention chirurgicale. J. frans. Méd. Chir. thorac., 5, 121.

Oberman, H. A. (1963). Sympathicoblastoma of the anterior mediastinum. Dis. Chest, 43, 314.

Pachter, M. R. (1963). Mediastinal nonchromaffin paraganglioma. $J$. thorac. cardiovasc. Surg., 45, 152. 
Parsons, P. B., and Platt, L. (1940). Calcification in abdominal neuroblastoma. Amer. J. Roentgenol., 44, 175.

Phillips, R. (1953). Neuroblastoma. Ann. roy. Coll. Surg. Engl., 12, 29.

Pinkel, D. (1962). Cyclophosphamide in children with cancer. Cancer, $15,42$.

Poole, G., and Deeley, T. J. (1963). Neurofibromatosis with malignant change. Amer. Rev. resp. Dis., 88, 65.

Poore, T. N., Dockerty, M. B., Kennedy, R. L. J., and Walters, W. (1951). Symposium on surgical aspects of cancer problem abdominal neuroblastomas. Surg. Clin. N. Amer., 31, 1121.

Potter, E. L., and Parrish, J. M. (1942). Neuroblastoma, ganglioneuroma and fibroneuroma in a stillborn fetus. Amer. J. Path., 18,141 .

Preston, F. W., Walsh, W. S., and Clarke, T. H. (1952). Cutaneous neurofibromatosis. Clinical manifestations and incidence of neurofibromatosis. Clinical manifestations and
sarcoma in 61 male patients. Arch. Surg., 64, 813 .

Rawles, M. E. (1947). Origin of pigment cells from the neural crest in the mouse embryo. Physiol. Zool., 20, 248.

Razemon, P., and Ribet, M. (1965). Remarques à propos de 21 cas de tumeurs nerveuses endothoraciques. Ann. chir. thorac. cardiovasc., 4 , p. C. 852 , C.T. 349.

Ringertz, N., and Lidholm, S. O. (1956). Mediastinal tumors and cysts. J. thorac. cardiovasc. Surg., 31, 458.

Sawitsky, A., and Desposito, F. (1965). A survey of American experience with vitamin B12 therapy of neuroblastoma. J. Pediat., 67, 99.

Schweisguth, O., Mathey, J., Renault, P., and Binet, J. P. (1959). Intrathoracic neurogenic tumors in infants and children: a study of forty cases. Ann. Surg., 150, 29.

Seaman, W. B., and Eagleton, M. D. (1957). Radiation therapy of neuroblastoma. Radiology, 68, 1.
Startz, I. S., and Abrams, J. (1938). Neuroblastoma. Ibid., 30, 232. Stone, L. S. (1929). Experiments showing the role of migrating neural crest (mesectoderm) in the formation of head skeleton and loose $\subseteq$ connective tissue in Rana palustris. Z. wiss. Biol. Abt. D. Wilhelm Roux Arch. EntwMech. Org., 118, 40.

Stout, A. P. (1935). The peripheral manifestations of the specific nerve sheath tumor (neurilemoma). Amer. J. Cancer, 24, 751.

Sutow, W. W. (1958). Prognosis in neuroblastoma of childhood. Amer. J. Dis. Child., 96, 299.

Swaen, G. J. V. (1966). Een geval van differentiërend neuroblastoom. Ned. T. Geneesk, 110, 115 .

Sweeney, M. J., Tuttle, A. H., Etteldorf, J. N., and Whittington, G. L. (1962). Cyclophosphamide in the treatment of common neoplastic $\vec{\omega}$ diseases of childhood. J. Pediat., 61, 702 .

Thorsrud, G. (1960). Neurinoma. Acta chir. scand., Suppl. 252.

Thurman, W. G., Fernbach, D. J., and Sullivan, M. P. (1964). Cyclophosphamide therapy in childhood neuroblastoma. New. Engl. N J. Med., 270, 1336.

Uhlmann, E. M., and Essen, C. von (1955). Neuroblastoma (neuro- $A$ blastoma sympatheticum). Pediatrics, 15, 402.

Vinik, M., and Altman, D. H. (1966). Congenital malignant tumors. $\underset{\perp}{\mp}$ Cancer, 19, 967.

Weiss, A. G., and Koebelé, F. (1955). Neurinome géant du médiastin. Poumon, 11, 109.

Wittenborg, M. H. (1950). Roentgen therapy in neuroblastoma. A review of seventy-three cases. Radiology, 54, 679.

Wyatt, G. M., and Farber, S. (1941). Neuroblastoma sympatheticum: roentgenological appearances and radiation treatment. Amer. $J$ Roentgenol., 46, 485 . 